\title{
COMPARISON OF FLORISTIC DIVERSITY OF FOUR WOODLAND TYPES IN THE UPPER HANTANA CAMPUS LAND
}

\author{
R M C S Ratnayake', I A U N Gunatilleke² and C V S Gunatilleke² \\ 1 Department of Botany, University of Kelaniya, \\ ${ }^{2}$ Department of Botany, University of Peradeniya
}

In the Upper Hantana campus land, three broad-leaf woodlands Peresereanthes falcataria, Alstonia macrophylla, or mixed species woodland and Pinus caribaea woodland grow in proximity to one another. The wide range of floristic diversity exhibited by these different woodlands was compared using plot sampling.

The overstorey vegetation of the Alstonia woodland showed the highest, i) density, ii) floristic richness, iii) proportion of endemics and iv) plant diversity, followed in decreasing order by that in the Peresereanthes-, mixed-, and Pinus woodland. In the understorey vegetation, floristic diversity $(<10 \mathrm{~cm})$ was highest in Peresereanthes woodland, followed in decreasing order by that in Alstonia-, mixed species-, and Pinus woodlands. Species rank abundance plots of overstorey and understorey species show that over storey vegetation in Pinus woodland, fits the geometric series, whereas the others fit the log series or log normal model.

The broad-leaf species woodlands in Upper Hantana also showed better natural regeneration of an array of species. All woodlands showed differences in micro-site conditions. Levels of human disturbance and burning may contribute to differences amongst them. These results provide baseline ecological information on natural regeneration in different woodland types and indicate their relative potential for conservation of biodiversity and water resources.

Proceedings of the Third Annual Forestry Symposium 1997, of the Department of Forestry and Environmental Science, University of Sri Jayewardenepura, Sri Lanka 